\title{
RESEARCH ON THE MICROBIOLOGICAL QUaLITY OF aIR IN NaVAL FaCILITIES
}

Zbigniew Dabrowiecki, Małgorzata Dąbrowiecka, Romuald Olszański, Piotr Siermontowski

Military Medical Institute, Institute of Maritime and Hyperbaric Medicine, Gdynia, Poland

\section{ABSTRACT}

Harmful biological factors accumulated in the ambient atmosphere are a very important and increasingly recognised problem of both occupational medicine and public health. The quantitative and qualitative assessment of harmful biological agents in the working environment is a very important element of the exposure assessment and therefore of an assessment of workers' health risks. In 2018, a pilot study on the microbiological quality of air was carried out at two facilities of the Polish Navy.

Keywords: work environment, air contamination, risk assessment.

\section{ARTICLE INFO}

PolHypRes 2019 Vol. 69 Issue 4 pp. 81 - 90

ISSN: 1734-7009 elSSN: 2084-0535

DOI: $10.2478 /$ phr-2019-0022

Pages: 10, figures: 3 , tables: 4

Original article

page www of the periodical: www.phr.net.pl

Submission date: 13.08.2019 r.

Publisher

Polish Hyperbaric Medicine and Technology Society 


\section{INTRODUCTION}

With the development of civilisation, the state of cleanliness of atmospheric air, as well as the air in enclosed spaces where people live, is constantly drastically deteriorating. The atmospheric air contains numerous components that create pollution. One of the elements having a significant impact on the air quality are biological pollutants, forming bioareosol, which includes: fungal spores, pollen, bacteria and viruses. The assessment of air pollution by harmful biological agents is an important problem for human health $[1,2,3]$.

The European Community issued Directive 2000/54/EC, which deals with the protection of workers from risks related to exposure to biological agents at work. The Directive, which sets out the employer's obligations with regard to the protection of workers from exposure to biological agents, includes a classification of biological agents that pose a risk in the workplace and describes safety measures and places where exposure to biological agents is particularly dangerous. Due to the possibility of an occurrence of harmful biological agents in indoor air, a qualitative and quantitative control of the level of microbiological air pollution is necessary [2]. In 2018, we conducted a pilot study on the microbiological quality of air in two facilities of the Polish Navy.

\section{HAZARDS ARISING FROM THE PRESENCE OF BIOLOGICAL POLLUTANTS IN THE AIR}

Biological harmful factors accumulated in the atmosphere around us are a very important and an increasingly recognised problem of both occupational medicine and public health. The quantitative and qualitative assessment of harmful biological agents in the working environment is a very important element of the exposure assessment and therefore of workers' health risks. Exposure to biological agents in the occupational and non-occupational environment is common and often leads to a wide range of adverse health effects, from simple irritations and ailments to allergic reactions and the occurrence of infections, infectious diseases and toxic reactions. The most common hazard in the working environment is posed by biological harmful agents as components of bioaerosols, which are airborne or air-drop transmitted and penetrate the body through the respiratory system $[4,5]$.

Most health problems related to air quality in the workplace are associated with exposure to mould, which accounts for about $70 \%$ of the total indoor air microflora. Moulds are a common cause of allergies in humans, leading to allergic rhinitis, conjunctivitis and asthma, as well as gastrointestinal infections. Many of the fungi we find in the air from the genera Aspergillus, Penicilinum, Fusarium or Stachybotris have toxigenic properties. There are many indications that mycotoxins and volatile metabolites of fungi may be the cause of the disease referred to as "chronic fatigue syndrome". [6,7,8] Bacteria generally make up $19-26 \%$ of the microflora in buildings. Most bacteria do not pose a health risk at low concentrations of these microorganisms in the air, but some have pathogenic, allergenic or toxic properties even in small quantities. Ventilation and air-conditioning systems are conducive to the growth of Legionella bacteria, which can cause legionellosis or Pontiac fever.
Biological particles suspended in the air may be a direct cause of allergies, asthma, and many other diseases [9]. Diseases, whose aetiological factors are transmitted through the air, include:

- viral: measles, chickenpox, influenza, mononucleosis, rubella, mumps (parotitis), herpes, meningitis,

- bacterial: bronchitis and pneumonia, rhinitis; lung tuberculosis, diphtheria, pertussis, scarlet fever, actinomycosis,

- fungal: aspergillosis of the lungs, lung mucorrhiza, lung cryptococcosis, bronchial mycosis, lung geotrichosis, fungal pneumonia, pleural mycosis and other $[6,10]$.

Attention should be paid to the fact that it's not only the presence of pathogenic micro-organisms or toxins of microbiological origin in the air that are a threat, but also an excessive amount of saprophytic micro-organisms, especially if their composition is non-diverse and they are dominated by organisms of a single species $[11,12,13]$.

\section{SOURCES OF BIOAEROSOL}

Microorganisms in the air most often occur in the form of bioareosols, i.e. suspended in the air on tiny particles of liquids, or dusts of plant, animal or mineral origin, which may contain spores and conidia of fungi, as well as bacteria and their spores [3]. Among harmful biological factors present in the air we can distinguish:

- Microorganisms causing infectious and invasive diseases - viruses, bacteria, fungi. Published results indicate the presence of fungi in air samples of the following genera: Aspergillus, Penicillium, Cladosporium and yeasts of the genus Candida. The bacterial microflora is poorer with prevalence of Gram-positive bacteria (Micrococcus spp., Staphylococcus spp., Bacillus spp.) $[1,5,6]$.

- Biological allergens - microscopic plant and animal particles. Among the components of bioaerosol it is possible to distinguish pollen, plant remains, animal dandruff, particles originating from peeling of the epidermis in humans and animals.

- Biological toxins - the presence of certain species of bacteria and fungi is also associated with the presence in the air of immunotoxic substances produced by these microorganisms, which include endotoxins, mycotoxins, glucans, volatile organic compounds or peptidoglycan. Endotoxins and $(1 \rightarrow 3)-\beta$-D-glucans are the products of cell wall degradation of Gramnegative bacteria and fungi respectively $[1,6]$.

- Biological vectors, i.e. arthropods carrying diseases such as mosquitoes, ticks, flies.

Internal air pollution can derive from both external and internal sources. External sources of microbiological air pollution can be divided into natural (soil, water, decomposition of organic matter, plant phyllosphere) and anthropogenic (landfills, sewage treatment plants, composting plants, livestock farms, agricultural holdings, car traffic and derivatives) [3].

Internal pollution can be caused by people, dusts of organic origin, materials accumulated in buildings and 
air penetrating through ventilation and air conditioning systems. One of the main sources of bioaerosols in rooms is people - sweat drops, saliva. Man is the main source of bacteria, because of the natural flora of human skin. The production of biological aerosol can occur by sneezing, coughing, as well as physical effort. Toilets are also a source of bioaerosols, owing to the high humidity, which contributes to the growth of mould fungi. Washbasins, showers and drains are a source of gram-negative bacilli. Microbiological contamination may be present in construction and finishing materials. Fibrous materials, insulating materials, gypsum boards can be an important source of living airborne microorganisms that can accumulate on filters and filtering equipment. As long as there is sufficient moisture, fungi can grow in almost all materials. The high cellulose content in some materials (e.g. ceiling panels) makes them an ideal environment for their growth. An important factor influencing indoor air quality is heating, ventilation and air conditioning, which is mainly provided in newly built buildings $[4,5,9]$.

\section{LEGAL REGULATIONS}

The control of microbiological purity of air in Polish and world legislation is insufficiently regulated at present. Unlike most chemical and physical agents, there are no commonly accepted criteria for assessing exposure to biological agents, as well as generally accepted normative values and methodological recommendations. This is primarily due to the fact that:

- still no satisfactory epidemiological data are available to establish the relationship between exposure to the agent and the health effect of the agent,

- the susceptibility of each organism exposed to a given biological harmful agent is an individual characteristic of that organism, which makes it difficult to clearly determine the effects of such an effect,

- $\quad$ source (measurement) data on the most common bioaerosols in the environment are still insufficient,

- there is a lack of standardisation of measuring methods (e.g. lack of standard samplers) and experimental methods [2].

At present, there are no legal acts in force in Poland which define the permissible content of microorganisms in the air, both atmospheric and indoor. The previously binding standards [PN-89/Z-04008/01; PN-89/Z-04008/08; PN-89/Z-04111/02; PN-89/Z04111/03] concerning atmospheric air pollution were repealed in 2015, but have not been replaced by new ones; therefore, in many studies on the assessment of microbiological purity of the air, the information on limit values of microbiological contamination contained therein is still used to interpret the obtained results.

The proposals of the team of experts on biological agents of the interministerial committee on Threshold Limit Values (TLV) and Permissible Exposure Limits (PEL) also deserve special attention. They present proposals of acceptable concentration values for groups of microorganisms commonly occurring in the air of working, residential and public spaces, developed on the basis of the results of environmental measurements, taking into account the potential harmfulness of particular biological factors. These proposals may form the basis for the development of generally accepted standards for harmful biological agents in indoor air and, in the meantime, may be considered as optional standards or reference values for the interpretation of microbiological air test results $[2,3,5]$.

Provisions contained in Directive 2000/54/EC of the European Parliament and of the Council of the European Union "on the protection of workers from risks related to exposure to biological agents at work" was implemented in Polish law by a relevant provision in the Labour Code. This resulted in the adoption by the Polish Committee for Standardisation of European acts PN-EN 13098 "Air at workplaces. Guidelines for measurement of microorganisms and endotoxins suspended in the air". (2002) and EN 14031 "Air at workstations. Monitoring of airborne endotoxins" (2004). A shortcoming of both legal acts and Directive 2000/54/EC is the absence of limit values for concentrations of micro-organisms and endotoxins in the air, which calls into question their effectiveness in protecting workers from risks related to exposure to biological agents at work. The implementation of quantitative standards based on an epidemiologically and experimentally proven relationship between the concentration of a given biological agent and the resulting health effects would make it possible to take precautionary measures and, in certain situations, preventive action [2].

\section{PILOT STUDIES ON MICROBIOLOGICAL AIR} QUALITY

Pilot studies were conducted in two Naval facilities: the Diver Training Centre and the vessel ORP "Kościuszko". The aim of the research was to test the developed method and preliminary estimation of the level and type of microbiological contamination of air and surrounding areas in selected places in these two facilities.

Air samples were taken using the impact method, which involves sucking an air stream onto a solid substrate intended for the isolation of the microorganisms to be determined. Tests were carried out using the Microflow a90 Microbiological Air Sampler. The apparatus automatically drew $100 \mathrm{dm} 3$ of air within 1 minute. Before sampling, the inside of the aeroscope was disinfected with sterile gauze soaked in $70 \%$ ethyl alcohol.

After suction, the air was directed through narrow holes to the head with a petri dish containing a suitable microbiological medium. Solid media suitable for isolated groups of microorganisms were used in the study. The total number of microorganisms was determined on a TSA medium, incubation was performed at $37^{\circ} \mathrm{C}$ for $24-48$ hours. In order to isolate staphylococci from the air, an MSA medium was used, which together with the air sample was incubated at $37^{\circ} \mathrm{C}$ for 24 hours. Moulds and yeasts were isolated on an SDA medium and then incubated at $28^{\circ} \mathrm{C}$ for $72-96$ hours. The number of colonies of the microorganisms to be determined was converted into the total number of colony-forming units (cfu) in $1 \mathrm{~m}^{3}$ air using the formula:

$$
\mathrm{L}=(\mathrm{Pr} \cdot 1000) / \mathrm{V}
$$

where:

$\mathrm{L}$ - total number of microbial colony-forming units (cfu) in $1 \mathrm{~m}^{3}$ air, $\mathrm{Pr}$ - umber of colonies grown on the substrate used, with statistical correction according to the aeroscope manufacturer's table, $\mathrm{V}$ - volume of air drawn $\left(\mathrm{dm}^{3}\right)$, 1000 - converted to $1 \mathrm{~m}^{3}$ air. 
Surface samples were taken using $25 \mathrm{~cm}^{2}$ imprint plates with a TSA (for total microbial count), Sabouraud Dextrose Agar (for mould and yeast counting) and Baird Parker Egg Yolk Tellurite (for Staplylococcus). Three to five samples were taken from the vicinity of the air sampling point to confirm the presence of the microbial types detected during the air test. Surface samples were incubated at $35^{\circ} \mathrm{C}$ for $24-48$ hours - bacteria and at $28^{\circ} \mathrm{C}$ for 72-96 hours - fungi.

The results obtained were calculated as $\mathrm{cfu} / \mathrm{m}^{3}$ and $\mathrm{cfu} / 100 \mathrm{~cm}^{2}$, respectively, the arithmetic mean of all the repetitions performed at a given location was taken as the final result.

\section{RESEARCH RESULTS}

The microbiological contamination varied, the number of microorganisms did not exceed the quantitative thresholds contained in PN-89/Z-04111/02 and PN-89/Z04111/03 standards and the developed proposal of the Team of Experts on Biological Agents of the Interministerial Commission on TLV and PEL. The dominant microorganisms in the air were filamentous fungi, which often constituted more than $60 \%-70 \%$ of the isolated organisms. The imprint samples taken from surfaces adjacent to the air sampling point also showed large amounts of mould fungi. In addition, the presence of Staphylococcus bacteria was detected in almost all the samples taken from the surfaces, and more than $50 \%$ contained S. aureus.

\begin{tabular}{|c|c|c|c|}
\hline Place of sampling & $\begin{array}{l}\text { Total number of } \\
\text { micro-organisms } \\
\text { TSA substrate }\end{array}$ & $\begin{array}{l}\text { Total quantity of } \\
\text { yeasts and moulds } \\
\text { SDA substrate }\end{array}$ & Notes \\
\hline $\begin{array}{l}\text { Main hall - point no. } 1 \text { at the } \\
\text { suits dryer }\end{array}$ & $260 \mathrm{cfu} / \mathrm{m}^{3}$ & $680 \mathrm{cfu} / \mathrm{m}^{3}$ & $\begin{array}{l}\text { presence of microorganisms of such genera } \\
\text { as: Aspergillus, Penicilinum, Cladosporium, } \\
\text { Rhizopus, Micorococcus }\end{array}$ \\
\hline $\begin{array}{l}\text { Main hall - point no. } 2 \text { at the } \\
\text { suits dryer }\end{array}$ & $150 \mathrm{cfu} / \mathrm{m}^{3}$ & $400 \mathrm{cfu} / \mathrm{m}^{3}$ & $\begin{array}{l}\text { presence of microorganisms of such genera } \\
\text { as: Aspergillus, Penicilinum, Cladosporium, } \\
\text { Micorococcus }\end{array}$ \\
\hline Main hall - the edge of the pool & $140 \mathrm{cfu} / \mathrm{m}^{3}$ & $450 \mathrm{cfu} / \mathrm{m}^{3}$ & $\begin{array}{l}\text { presence of microorganisms of such genera } \\
\text { as: Aspergillus, Mucor, Penicilinum, } \\
\text { Cladosporium }\end{array}$ \\
\hline Main hall - running tracks & $640 \mathrm{cfu} / \mathrm{m}^{3}$ & $540 \mathrm{cfu} / \mathrm{m}^{3}$ & $\begin{array}{l}\text { presence of microorganisms of such genera } \\
\text { as: Aspergillus, Penicilinum, Cladosporium, }\end{array}$ \\
\hline Shower room 1 & $100 \mathrm{cfu} / \mathrm{m}^{3}$ & $330 \mathrm{cfu} / \mathrm{m}^{3}$ & $\begin{array}{l}\text { presence of microorganisms of such genera } \\
\text { as: Aspergillus, Mucor, Penicilinum, } \\
\text { Cladosporium }\end{array}$ \\
\hline Shower room 2 & $230 \mathrm{cfu} / \mathrm{m}^{3}$ & $440 \mathrm{cfu} / \mathrm{m}^{3}$ & $\begin{array}{l}\text { presence of microorganisms of such genera } \\
\text { as: Staphylococcus, Aspergillus, Mucor, } \\
\text { Penicilinum, Cladosporium }\end{array}$ \\
\hline Toilet & $100 \mathrm{cfu} / \mathrm{m}^{3}$ & $190 \mathrm{cfu} / \mathrm{m}^{3}$ & $\begin{array}{l}\text { presence of microorganisms of such genera } \\
\text { as: Mucor, Penicilinum, Cladosporium }\end{array}$ \\
\hline Office space at the Main hall & $230 \mathrm{cfu} / \mathrm{m}^{3}$ & $330 \mathrm{cfu} / \mathrm{m}^{3}$ & $\begin{array}{l}\text { presence of microorganisms of such genera } \\
\text { as: Staphylococcus, Aspergillus, Rhizopus, } \\
\text { Penicilinum, Cladosporium }\end{array}$ \\
\hline
\end{tabular}

\begin{tabular}{llll}
\multicolumn{1}{c}{ Air test results - samples taken on the ORP Kościuszko on 19.10.2018. } & $\begin{array}{l}\text { Total number } \\
\text { micro-organisms } \\
\text { TSA substrate }\end{array}$ & $\begin{array}{l}\text { Total quantity of } \\
\text { yeasts and moulds } \\
\text { SDA substrate }\end{array}$ & Notes \\
\hline Engine room with engine running & $140 \mathrm{cfu} / \mathrm{m}^{3}$ & $210 \mathrm{cfu} / \mathrm{m}^{3}$ & $\begin{array}{l}\text { presence of microorganisms of such } \\
\text { genera as: Aspergillus, Penicilinum, } \\
\text { Cladosporium }\end{array}$ \\
\hline Mess - at lunch & $445 \mathrm{cfu} / \mathrm{m}^{3}$ & $600 \mathrm{cfu} / \mathrm{m}^{3}$ & $\begin{array}{l}\text { presence of microorganisms of such } \\
\text { genera as: Aspergillus, Mucor, } \\
\text { Penicilinum, Cladosporium }\end{array}$ \\
\hline
\end{tabular}


Results of surface cleanliness tests - samples taken at OSN on 16.10.2018

\begin{tabular}{|c|c|c|c|c|}
\hline Place of sampling & $\begin{array}{l}\text { Total number of } \\
\text { micro-organisms } \\
\text { TSA substrate } \\
\mathrm{cfu} / 100 \mathrm{~cm}^{2}\end{array}$ & $\begin{array}{l}\text { Total quantity of } \\
\text { yeasts and moulds } \\
\text { SDA substrate } \\
\mathrm{cfu} / 100 \mathrm{~cm}^{2}\end{array}$ & Notes & \\
\hline $\begin{array}{l}\text { Main hall - areas near the diving suit } \\
\text { warehouse }\end{array}$ & $80 \mathrm{cfu}$ & $240 \mathrm{cfu}$ & $\begin{array}{l}\text { presence of } \\
\text { microorganisms }\end{array}$ & Staphylococcus \\
\hline $\begin{array}{l}\text { Main hall - the interior of the } \\
\text { "chopper" }\end{array}$ & $120 \mathrm{cfu}$ & $280 \mathrm{cfu}$ & $\begin{array}{l}\text { presence of } \\
\text { microorganisms }\end{array}$ & Staphylococcus \\
\hline $\begin{array}{l}\text { Main hall - areas at the edge of the } \\
\text { pool }\end{array}$ & $96 \mathrm{cfu}$ & $300 \mathrm{cfu}$ & $\begin{array}{l}\text { presence of } \\
\text { microorganisms }\end{array}$ & Staphylococcus \\
\hline $\begin{array}{l}\text { Main hall - areas around the running } \\
\text { tracks }\end{array}$ & $160 \mathrm{cfu}$ & $320 \mathrm{cfu}$ & $\begin{array}{l}\text { presence of } \\
\text { microorganisms }\end{array}$ & Staphylococcus \\
\hline Main hall - treadmill control panel & $72 \mathrm{cfu}$ & $256 \mathrm{cfu}$ & $\begin{array}{l}\text { presence of } \\
\text { microorganisms }\end{array}$ & Staphylococcus \\
\hline Shower room no. 1 & $100 \mathrm{cfu}$ & $60 \mathrm{cfu}$ & & \\
\hline Shower room no. 2 & $280 \mathrm{cfu}$ & $240 \mathrm{cfu}$ & $\begin{array}{l}\text { presence of } \\
\text { microorganisms }\end{array}$ & Staphylococcus \\
\hline Toilet flat surfaces & $360 \mathrm{cfu}$ & $92 \mathrm{cfu}$ & $\begin{array}{l}\text { presence of } \\
\text { microorganisms }\end{array}$ & Staphylococcus \\
\hline Office space at the Main Hall & $504 \mathrm{cfu}$ & $320 \mathrm{cfu}$ & $\begin{array}{l}\text { presence of } \\
\text { microorganisms }\end{array}$ & Staphylococcus \\
\hline
\end{tabular}

Results of surface cleanliness tests - samples taken on the ORP Kościuszko on 19.10.2018.

\begin{tabular}{|c|c|c|c|c|}
\hline Place of sampling & $\begin{array}{l}\text { Total number of } \\
\text { micro-organisms } \\
\text { TSA substrate } \\
\text { cfu/100 } \mathrm{cm}^{2}\end{array}$ & $\begin{array}{l}\text { Total quantity of } \\
\text { yeasts and moulds } \\
\text { SDA substrate } \\
\text { cfu/ } 100 \mathrm{~cm}^{2}\end{array}$ & Notes & \\
\hline Mess - table surfaces & $352 \mathrm{cfu}$ & $384 \mathrm{cfu}$ & $\begin{array}{l}\text { presence of } \\
\text { microorganisms }\end{array}$ & Staphylococcus \\
\hline Mess - seat-back & $>1200 \mathrm{cfu}$ & $88 \mathrm{cfu}$ & $\begin{array}{l}\text { presence of } \\
\text { microorganisms }\end{array}$ & Staphylococcus \\
\hline Mess - surface by coffee thermos & $>1200 \mathrm{cfu}$ & $68 \mathrm{cfu}$ & $\begin{array}{l}\text { presence of } \\
\text { microorganisms }\end{array}$ & Staphylococcus \\
\hline Mess - refrigerator door surface & $200 \mathrm{cfu}$ & $16 \mathrm{cfu}$ & & \\
\hline
\end{tabular}

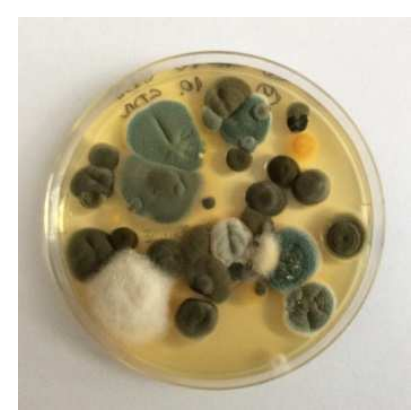

Fig. 1 Diver Training Centre - air sampling point - Main Hall, edge of the pool.

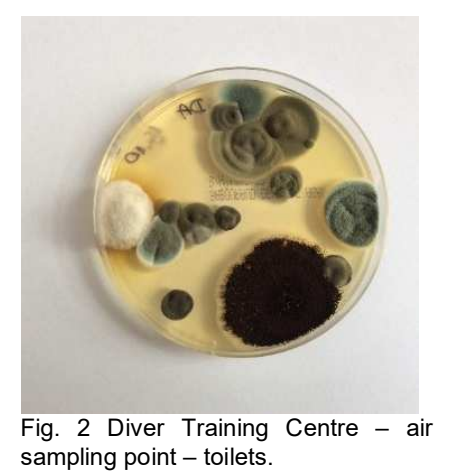

sampling point - toilets.

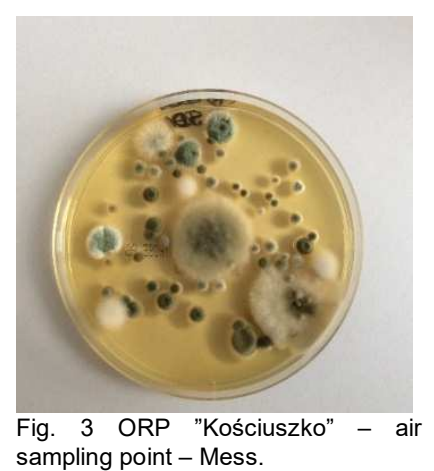

Fig. 3 ORP "Kościuszko" - air sampling point - Mess. 


\section{ConClusions}

The data presented are preliminary studies. It is advisable to further monitor the degree of air pollution in these and other Naval facilities in order to assess the impact of microbial concentrations in the air on the health of soldiers and civilian workers. It was found in the presented studies that the average total number of microorganisms in the air did not exceed the values presented in the standards no longer in force or the limit values presented in the proposal of the Team of Experts. It was shown that in both facilities the concentration of moulds and yeasts in $1 \mathrm{~m}^{3}$ of air is higher than the concentration of bacterial bioareosol, which can be explained by increased humidity, especially in the Diver Training Centre.

\section{REFERENCES}

1. Bródka K., Sowiak M., Kozajda A., Cyprowski M., Szadkowska-Stańczyk I. Biological factors influencing air quality in office premises. Medycyna Pracy $2012 ; 63(3)$ s. 303-315;

2. Górny R. Harmful biological agents: standards, recommendations and proposals for limit values. Podstawy Metody Oceny Środowiska Pracy. $2004 \mathrm{Nr} 3$ (41) s. 17-39;

3. Chmiel M.J., Frączek K., Grzyb J. Problems of microbiological air pollution monitoring. Woda-Środowisko-Obszary Wiejskie. 2015 T. 15. Z. 1 (49) s. 17-27;

4. Prędecka A., Kosut S. Analysis of microbiological hazards in indoor air on the example of pollution in selected rooms of the Main School of Fire Service. Zeszyty Naukowe SGSP 2017 no. 62(vol.1);

5. Gaska-Jẹdruch U., Dudzińska M. Microbiological contamination of indoor air. W: Polska Inżynieria Środowiska pięć lat po wstapieniu do Unii Europejskiej. 2009 Collective work. Ed. J. Ozonek, A. Pawłowski. T. 2. Lublin. PAN pp. 31-40;

6. Skóra J., Zduniak K., Gutarowska B., Rembisz D. Harmful biological agents in museum workstations. Medycyna Pracy 2012;63(2):153-165;

7. Wiszniewska M., Walusiak J., Gutarowska B., Żakowska Z., Pałczyńki C. Moulds in the communal environment and workplace - significant health risk Medycyna Pracy 2004;55(3):257-266

8. Nielsen K.F., Gravesen S., Nielsen P.A., Andersen B., Thrane U., Frisvad J.C. Production of mycotoxinson on artificially and naturally infested building materials. Mycopathologia 1999; 145:43-56;

9. Kim K.H.,Jahan S.A.,Kabir E. A review on human health perspective of air pollution with respect to allergies and asthma. Environment International. 2013 Vol. 59 pp. 41-52;

10. Chróst A. Moulds in the human environment - health hazards and effects. Med.Dośw.Mikrobiol. 2016, 68 pp. 135-150;

11. Cabral J.P.S. Can we use indoor fungi as bioindicators of indoor air quality? Historical perspectives and open questions. Science of the Total Environment 2010 Vol. 408 pp. 4285-4295;

12. Gładysz J., Grzesiak A., Nieradko-Iwanicka B., Borzęcki A. The effect of air pollution on human health and life expectancy. Problemy Higieny i Epidemiologii 2010 Vol. 91. No. 2 pp. 178-180;

13. Flannigan B., Samson R.A., Miller J.D. Microorganisms in home and indoor work environments. Diversity, health impacts, investigation and control 2011 Ed. 2. London. CRC Press. ISBN 9781420093346 pp. 539

dr n. biol. Zbigniew Dąbrowiecki

Zakład Medycyny Morskiej i Hiperbarycznej

Wojskowy Instytut Medyczny

ul. Grudzińskiego 4 81-103 Gdynia 3 skr. poczt. 18 tel: 604291581

e-mail: zdabrowiecki@wim.mil.pl 